\title{
PERBEDAAN PRESTASI BELAJAR BIDANG STUDI EKONOMI MELALUI MODEL PEMBELAJARAN TWO STAY TWO STRAY DAN EXPLICIT INSTRUCTION MATERI POKOK KONSUMSI PESERTA DIDIK DI KELAS X SMA MUHAMMADIYAH 15 SIBOLGA TAHUN PELAJARAN 2016-2017
}

\author{
Yani Sukriah Siregar ${ }^{(1)}$ dan Riski Baroroh ${ }^{(2)}$ \\ ${ }^{(1,2)}$ Dosen FKIP Univeristas Muhammadiyah Tapanuli Selatan
}

\begin{abstract}
Abstrak
Penelitian ini bertujuan untuk mengetahui apakah ada perbedaan prestasi belajar peserta didik melalui model pembelajaran two stay two stray dan explicit instruction materi pokok konsumsi peserta didik di kelas X SMA Muhammadiyah 15 Sibolga tahun pelajaran 2016-2017. Jenis penelitian yang digunakan oleh peneliti adalah penelitian komparatif, yaitu penelitian yang bersifat membandingkan variabel yang satu dengan variabel yang lain terhadap objek yang berbeda.Pendekatan yang digunakan adalah pendekatan penelitian kepustakaan, dan pendekatan penelitian lapangan yaitu pendekatan yang dilakukan oleh peneliti secara langsung baik menggunakan angket, atau pun tesPopulasi dalam penelitian ini adalah seluruh kelas $X$ semester 2 SMA Muhammadiyah 15 Sibolga sebanyak 40 orang peserta didik yang terdiri dari 2 kelas yaitu kelas $X-1$ dan kelas $X$-2.Sampel penelitian berjumlah 40 orang peserta didik, yang terdiri dari 2 kelas yaitu kelas $X-1$ dan $X$-2. Hasil penelitian dengan menggunakan rumus " $t$-test polled varians" maka diperoleh $t_{\text {hitung }}$ senilai 2,240 dengan melihat daftar $t_{\text {tabel }}$ dengan jumlah sampel 40 kemudian digunakan derajat kebebasan (dk) $=n_{1}+n_{2}-2$ dan taraf kesalahan 5\% $(2,021)$.
\end{abstract}

Kata Kunci: Prestasi Belajar, Model Pembelajaran, Two Stay Two Stray

\section{Pendahuluan}

Pendidikan adalah salah satu bentuk perwujudan kebudayaan manusia yang dinamis dan syarat pengembangan. Oleh karena itu perubahan atau perkembangan pendidikan adalah hal yang memang seharusnya terjadi sejalan perubahan budaya kehidupan. Perubahan dalam arti perbaikan pada semua tingkat perlu terus menerus dilakukan sebagai antisipasi kepentingan masa depan. 
Prestasi adalah suatu hasil yang dicapai mengenai pendidikan dan pembelajaran. Sementara prestasi belajar di bidang pendidikan adalah hasil dari pengukuran terhadap peserta didik yang meliputi faktor kongnitif, afektif, dan psikomotorik, setelah mengikuti proses pembelajaran yang di ukur dengan menggunakan instrumen tes atau instrumen yang relevan. Jadi prestasi belajar adalah hasil pengukuran dari penilaian usaha belajar yang dinyatakan dalam bentuk simbol, huruf,maupun kalimat yang menceritakan prestasi yang sudah dicapai oleh setiap peserta didik.Salah satu faktor yang menjadi tolak ukur keberhasilan belajar adalah prestasi belajar. Untukitu guru sangat berperan sebagai pembimbing dalam melaksanakan proses belajar mengajar agar tercapai tujuan belajar.

Berdasarkan dari observasi yang telah dilakukan peneliti di SMA Muhammadiyah 15 Sibolga menunjukkan bahwa prestasi belajar peserta didik masih rendah. Hal ini sesuai dengan hasil wawancara guru ekonomi pada tanggal 26 oktober 2016 di SMA Muhammadiyah 15 Sibolga. Penerapan model pembelajaran kurang menarik, peralatan belajar kurang lengkap, peserta didik kurang menyukai pelajaran ekonomi, metode yang di gunakan tidak sesuai dengan materi yang di ajarkan sehingga menyebabkan rendahnya prestasi belajar peserta didik. Selain itu bukti yang kuat setelah peneliti menyebarkan angket dan tes diagnostik ditemukan rendahnya prestasi belajar peserta didik.
Dari hasil angket dan tes diagnostik yang peneliti adakan di kelas X SMA Muhammadiyah 15 Sibolga dari 40 peserta didik hanya 17 peserta didik yang mencapai KKM, sedangkan 23 peserta didik lainnya belum mencapai KKM, dari prestasi belajar tersebut diketahui bahwa prestasi belajar peserta didik masih rendah.

Pembelajaran tidak selamanya dapat berjalan mulus terkadang kita menjumpai adanya hambatan terutama gejala fisik dan masa bodoh dari peserta didik dalam mengikuti kegiatan proses belajar mengajar sehingga menyebabkan rendahnya prestasi belajar peserta didik.

Banyak cara, metode dan model pembelajaran yang bisa diterapkan oleh guru dalam proses pembelajaran. Agar peserta didik aktif dan berprestasi dalam belajar. Beberapa model pembelajaran yang dapat digunakan di antaranya adalah model pembelajaran two stay two stray dan explicit instruction.

\section{Metode Penelitian}

Metode pengambilan sampel dalam penelitian ini adalah sampel populasi, dimana seluruh populasi dijadikan sampe penelitian.Sampel penelitian nya adalah sebanyak 2 kelas yang terdiri dari 40 orang peserta didik, setiap kelas berhak menjadi sampel dalam penelitian, yaitu kelas X-1 dan kelas X-2. Untuk memperoleh data yang diperlukan dalam proposal ini peneliti mengambil data berdasarkan angket dan tes. Data-data yang sudah terkumpul kemudian akan dilakukan analisa lebih lanjut,untuk menguji hipotesis yang ditetapkan dalam 
penelitian ini yaitu menggunakan rumus " $t$ test polled varians.

\section{Pembahasan dan Hasil}

Setelah data diperoleh melalui penelitian dilapangan maka data tersebut akan dianalisis untuk memberikan gambaran tentang perbedaan prestasi belajar bidang studi ekonomi melalui model pembelajaran two stay two stray materi pokok konsumsi peserta didik di kelas X SMA Muhammadiyah 15 Sibolga tahun pelajaran 2016-2017.

Dari data yang diperoleh di atas maka dapat dilihat nilai yang tertinggi 93 dan nilai yang terendah 53. Langkahselanjutnya peneliti akan menghitung data angket dan data prestasi belajar peserta didik dengan menggunakan model pembelajaran two stay two stray pada materi pokok konsumsi di kelas X-1 SMA Muhammadiyah 15 Sibolga.

Dari perhitungan menggunakan t-test polled varians maka diperoleh $t_{\text {hitung }}$ nya senilai 2,240 dengan melihat daftar $t_{\text {tabel }}$ dengan jumlah sampel 40 kemudian digunakan derajat kebebasan $(\mathrm{dk})=\mathrm{n}_{1}+\mathrm{n}_{2}-$ 2 dan taraf kesalahan 5\% (2,021). Sesuai dengan ketentuan jika $t_{\text {hitung }}>t_{\text {tabel }}(2,240>$ 2,021) maka hipotesis alternatif (Ha) dapat diterima kebenarannya.

Jadi, menurut perhitungan hipotesis alternatif (Ha) penelitian ini menyatakan kebenarannya bahwa: “ada perbedaan prestasi belajar bidang studi ekonomi melalui model pembelajaran two stay two stray materi pokok konsumsi peserta didik di kelas X SMA Muhammadiyah 15 Sibolga tahun pelajaran 2016-2017”.

Dalam penelitian ini peneliti membahas suatu permasalahan yaitu: “ apakah ada perbedaan prestasi belajar bidang studi ekonomi melalui model pembelajaran two stay two stray dan explicit instruction materi pokok konsumsi peserta didik di kelas X SMA Muhammadiyah 15 Sibolga tahun pelajaran 2016-2017”.

Ternyata setelah dilakukan pengujian hipotesis dengan rumus t-test polled varians diperoleh hasil $t_{\text {hitung }}=2$,240sedangkan nilai $t_{\text {tabel }}=2,021$ ini menunjukkan $t_{\text {hitung }}>t_{\text {tabel }}$ artinya ada perbedaan prestasi belajar bidang studi ekonomi melalui model pembelajaran two stay two stray dna explicit instruction materi pokok konsumsi peserta didik di kelas X SMA Muhammadiyah 15 Sibolga tahunpelajaran 2016-2017.

\section{Kesimpulan}

Berdasarkan hasil analisis yang telah peneliti lakukan, dapat disimpulkan bahwa:

1. Ada perbedaan prestasi belajar peserta didik melalui model pembelajaran two stay two stray dan explicit instruction pada materi pokok konsumsi di SMA Muhammadiyah 15 Sibolga tahun pelajaran 2016-2017. Hal ini dapat dibuktikan dari nilai $t_{\text {hitung }}=2,240$ dengan melihat daftar tabel jumlah sampel nya 40 dan derajat kebebasan $(\mathrm{dk})=\mathrm{n}_{1}+\mathrm{n}_{2}-2$ untuk taraf kesalahan 5\% (2,021)sehingga dapat diketahui $t_{\text {hitung }}>$ 
$t_{\text {tabel }} \quad(2,240>\quad 2,021) \quad$ makahipotesis alternatif (Ha) dapat diterima.

2. Perbedaan prestasi belajar peserta didik melalui model pembelajaran two stay two stray dan explicit instruction memperoleh $t_{\text {hitung }}=2,240$ dan $t_{\text {tabel }}=2,021$ dengan ketentuan jika $t_{\text {hitung }}>t_{\text {tabel }}$ maka $\mathrm{Ha}$ diterima dan Ho ditolak. Jadi kesimpulan dari penelitian ini yaitu ada pebedaan prestasi belajar antara model pembelajaran two stay two stray dan explicit instuction karena Ho ditolak dan Ha diterima.

3. Terdapat gambaran bahwa model pembelajaran two stay two stray lebih baik dari pada model pembelajaran explicit instruction dengan ini terlihat dalam penelitian yang dilakukan peneliti di SMA Muhammadiyah 15 Sibolga tahun pelajaran 2016-2017.

\section{Saran}

Untuk mengakhiri dari skripsi ini peneliti menulis saran-saran di bawah ini sebagai berikut:

1. Kepada peserta didik sebagai subjek belajar untuk lebih meningkatkan penguasaan terhadap materi pembelajaran.

2. Kepada guru diharapkan untuk dapat meningkatkan kemampuan dalam mengajar dan selalu memperhatikan peserta didik dalam proses belajar mengajar serta memberikan motivasimotivasi terhadap peserta didik.

3. Sebagai bahan masukan buat peneliti lainnya yang nantinya akan melakukan penelitian pada permasalahan yang sama dengan maksut untuk memperkokoh data-data sehingga memperoleh prestasi yang lebih baik dan bermanfaat.

\section{Daftar Pustaka}

Arikunto, Suharsimi.2010.Prosedur Penelitian (Suatu pendekatan praktek),Jakarta: Rineka Cipta

Arikunto, Suharsimi, 2009,Manajem en Penelitian, Jakarta: Rineka cipta

Aadesanjaya.2012.Evaluasi Pembela jaran. Jakarta: Balai pustaka

Adnyana Metta. 2011.Model PembelajaranInovatif. Sidoarjo: Masmedia

Andi yusuf. 2009.Pengaruh Model Pembelajaran Kooperatif Model Dua Tinggal DuaTamu Two Stay Two Stray (TSTS) Terhadap Prestasi Belajar.

Bungin Burhan. 2011.Metodologi penelitian kuantitatif, Jakarta:Alfabeta 